Anuario Latinoamericano Ciencias Políticas

y Relaciones Internacionales

vol. 6, 2018

pp. 213-234

\section{The development of narcotrafficking and corruption in Mexico}

\section{El desarrollo del narcotráfico y la corrupción en México}

\author{
Nubia Nieto \\ INDEPENDENT RESEARCHER \\ $\triangle$ continents.sky@gmail.com \\ https://orcid.org/0000-0001-9454-5922
}

\begin{abstract}
In recent decades, Mexico has hit the news headlines due to the high levels of violence, brutality and drug trafficking. Moreover, the links between political power, intelligence agencies, corruption and organised crime have been undeniable in the development of narcotrafficking and violence in Mexico. In this scenario, the following questions are emerging and are intended to be analyzed throughout this text: Why have drug traffickers managed to destabilize the Mexican government? How much responsibilities have the U.S. and Mexican intelligence agencies in the development of drug trafficking and violence? Can Mexico by itself control the development of drug trafficking? Is it possible to establish the rule of law and accountability mechanisms? Does the new government of Andrés Manuel López Obrador represent hope for the control of violence in Mexico?
\end{abstract}

KEYWORDS: corruption, drug trafficking, political elites, Mexico, democracy.

\section{RESUMEN}

En las últimas décadas, México ha encabezado los titulares en la prensa debido a los altos niveles de violencia, brutalidad y tráfico de drogas. Además, pocas veces se cuestionan los vínculos entre poder político, agencias de inteligencia, corrupción $y$ crimen organizado en el desarrollo del narcotráfico y violencia en México. En este escenario, emergen las siguientes preguntas, las cuales se intentan analizar a lo largo del texto: ¿Por qué los narcotraficantes han logrado desestabilizar al gobierno mexicano? ¿Cuánta responsabilidad tienen las agencias de inteligencia de los Estados Unidos y México en el desarrollo del narcotráfico y la violencia? ¿Puede México controlar por sí mismo el desarrollo del tráfico de drogas? ¿Es posible establecer el Estado de derecho y los mecanismos de rendición de cuentas? ¿Representa el nuevo gobierno de Andrés Manuel López Obrador una esperanza para el control de la violencia en México?

PALABRAS CLAVE: corrupción, narcotráfico, élites políticas, México, democracia. 


\section{Introduction}

The development of drug trafficking in Mexico is relatively recent. Before the 1920's, marijuana production was mainly used among Mexican people for medicinal and ritualistic purposes, and opium cultivation was almost unknown. During the Second World War (1939-1945), the United States of America required huge amounts of morphine and other drugs to help American soldiers face the battlefield (Astorga 1999).

In Mexico, the use and consumption of drugs "was not a widespread phenomenon and the number of consumers was far less than the figures of its northern neighbour" (Astorga 1999: 12). At the end of the forties and with the end of the Second World War, the U.S government launched a very active and intensive campaign to convince other countries to accept opium control, later on imposing restrictions on marijuana and cocaine, since addiction to drugs among American population experienced a big increase. As the restrictions on these products increased, the demand and price rose, creating a new market of opportunities for criminal groups. Today, Mexico is a major source and transit country for heroin, marijuana and synthetic drugs destined for the United States and a main transit country for cocaine from South America. According to the International Narcotics Control Strategy Report 2017, in Mexico the illicit drug production rose from 250 metric tons in 2011 to 600 in 2015 (BINLEA 2017: 215). It is estimated that Mexican cartels generate "a profit of $\$ 6.6$ billion in gross revenue annually just from exporting drugs to the US alone" (Gutiérrez 2018). Simultaneously, "the country has had over 200,000 drug-related killings since 2006. Last year alone -2017-, 29,168 homicides were recorded, reaching the highest homicide rate over the last 20 years" (Gutiérrez 2018).

In this scenario, the present text tries to analyse the relation among political power, corruption, criminal groups and intelligence agencies, and their role in the development of narco-trafficking and violence in Mexico. This text attempts to unravel the following questions: Why are the drug traffickers able to destabilize the government? How much responsibility does the US and Mexican intelligence agencies have in the development of the violence in Mexico? Can Mexico by itself control the development of drug trafficking? Will it be possible to establish the rule of law and accountability mechanisms under the government of Andrés Manuel López Obrador? The main hypothesis set out in this text is a possible correlation between corruption and increase of criminal activities such as narcotrafficking. The corruption described in the text is oriented towards the political elites and intelligence agencies, which hypothetically have eased the development of the narcotrafficking and violence in Mexican. The present text follows a descriptive methodology based on qualitative and quantitative data, press publications, articles, global reports and academic information. 


\section{A brief background of narcotrafficking in Mexico: The role of U.S. agencies}

The development of drug trafficking in Mexico can be traced after the 1920's, when marijuana and opium production started to be exported to the U.S.A. Opium production was introduced to Mexico by Chinese immigrants, notably by Antonio Wong Yin, who was a "compadre" - godfather - of governor of Coahuila, Nazario Ortiz Garza (1929-1933). He was also close to General Jesús García Gutiérrez, who was in charge of military operations in the state at that time (Astorga 1999: 13).

In the United States up until the early 1900's, opium, cocaine, marijuana and alcohol were legal and they could be purchased at pharmacies and stores. In 1914, the Harrison Act was passed, prohibiting the sale of opium, morphine, and cocaine (Redmond 2013). At the same time, the Mexican revolution (1910-1917) was taking place, and revolutionary leaders in Mexico were more interested in institutionalizing the political life than in controlling opium trafficking (Astorga 1999: 11). Following the end of the Second World War (1939-1945), the U.S. government launched an intensive campaign against opium production in an attempt to control the addiction of soldiers returning from war. In order to enforce prohibition, the American state created new law enforcement agencies that over time became politically and financially involved in the continuation of prohibitionist drug policies. The Central Intelligence Agency (CIA) was established in 1947, and the Drug Enforcement Administration (DEA) was founded in 1973 (Buendía 1983). In the same year 1947, in Mexico, President Miguel Alemán Valdés (1946-1952) created the Security Federal Directorate (Dirección Federal de Seguridad - DFS), as a police force with the power to intervene in drug issues. The drug policy, traditionally managed by the Department of Health in Mexico, was transferred to the Attorney General Office (Procuraduría General de la República - PGR) also in the same year (Astorga 1999: 12). The DFS was in part a CIA creation, and the CIA presence in the DFS became so dominant for its intelligence that only "American eyes" could see and report operations of the DFS, as the famous Mexican journalist Manuel Buendía used to say (Buendía 1983: 24).

For Dale Scott, the complexity of the narcotrafficking in Mexico responds to the complexity of the narcotrafficking worldwide and its links with the U.S intelligence. According to Dale, there are three levels to see the phenomenon of narcotrafficking. The first one is "the demand side", which is related to consumers, mainly in rich countries. The second one is "the supply side", which is related to production and distribution of drugs, particularly in deprived communities. The third one is "the protected intelligence-drug connection" (Dale 2000: 2). Dale focuses his analysis of the development of narcotrafficking on the third factor, the one related to the protected intelligence-drug connection:
The development of narcotrafficking and corruption in Mexico Nubia Nieto 
History suggests that this third aspect of the drug problem, the protected intelligence-drug connection, or what I call government-drug symbiosis, has been responsible for the biggest changes in the patterns and level of drugtrafficking (...) researchers are becoming aware of a third aspect to the problem: protected intelligence drug connections. Within the U.S. governmental bureaucracy itself, intelligence agencies and special warfare elements have recurrently exploited drug traffickers and their corrupt political allies for anti-communist or anti-subversive operations (...) to strengthen right-wing power (...) One sees elsewhere this recurring pattern of CIA collaboration with intelligence and security networks who are allied with the biggest drug traffickers, not opposed to them. (Dale 2000: 2-4)

According to Dale, the "War on Drugs" is one of the narratives of the U.S. security agencies to justify their presence abroad and get financial resources from the U.S Congress: “This hypocrisy of 'anti-drug campaigns' dates back to 1974, the year when Congress cut back U.S aid programs to repressive Latin American police forces, and then beefed up so-called anti-narcotics aid to the same forces by about the same amount. To keep the aid coming, corrupt Latin American politicians helped to invent the spectre of the drug-financed narcoguerrillas" (Dale 2000: 3). Dale takes the case of Mexico to illustrate the "CIAdrug symbiosis": "In Mexico, for example, the CIA's closest government allies were for years in the DFS or Dirección Federal de Seguridad, whose badges, handed out to top-level Mexican drug-traffickers, have been labelled by DEA agents a virtual 'licence to traffic' (Dale 2000: 3)”. Therefore, during many years, "the arrest of narcotraffickers in Mexico was determined by a change of U.S. priorities and de facto alliances made with new drug figures", as U.S. intelligence agencies have always exploited traffickers and corrupt political elites to their own interest (Dale 2000: 2-3).

On the other hand, the predominance of US intelligence agencies over their counterpart in Mexico is overwhelming. The US has never respected Mexican sovereignty. The US Department of Treasury, the forerunner of the DEA, can send agents into Mexico without permission to gather intelligence on drug smugglers and to arrest and extradite suspects as they wish. On the opposite way, Mexican officials require a visa to enter the United States to carry out the same activities, and the State Department and the Bureau of Narcotics can turn down the request. Mexico does not have this prerogative. This double standard is still in effect today (Redmond 2013). The geographical proximity between Mexico and the United States is critical in the development of drug trafficking, the first as a producer and transit territory, and the second as a consumer and final destination. Exports of Mexican opium, heroin, and marijuana for the US consumption have increased due to the laws prohibiting these products and the Vietnam War (1955-1975) (Redmond 2013).

The production and trade of drugs has been developed under the umbrella of the US and Mexican authorities since the beginning. An example of the 
CIA-drug alliance is the cartel of Guadalajara, which was the most powerful cartel in the early 1980's and it enjoyed protection of the DFS, under its chief Miguel Nazar Haro (1978-1982). Nazar was a CIA asset. He led a dirty war against leftist insurgents and political opponents. Another example was José Antonio Zorrilla, former chief of the DFS during Miguel De la Madrid government (1982-1988), who provided credentials to traffic to Rafael Caro Quintero, leader of the cartel of Guadalajara. Zorrilla was a CIA asset too (Dale 2000).

\section{The narcotrafficking under the Mexican political system}

People who tried autonomous strategies for producing or smuggling drugs in Mexico did not last very long or just survived modestly, since the big drug business was dominated by high-ranking members of the anti-narcotics police and political elites during the ruling of the Institutional Revolutionary Party $(\mathrm{PRI})^{1}$. Every time there was a drug scandal involving Mexican politicians, nobody was ever prosecuted. The protection of the establishment was paramount, and any arising conflict was negotiated inside of the political elite, particularly through the PRI. It is important to remember that the PRI was created to institutionalize political and social demands and group all caudillos - local leaders - under the umbrella of one political party through its corporate structure (Anguiano 1975: 136-137). The corporate structure of the PRI was developed by grouping the National Peasant Confederation (CNC), the Confederation of Mexican Workers (CTM) and the National Confederation of the Popular Organisations (CNOP). The PRI operated as an engine of political control, a channel for managing social demands, a machine for political mobility and a centre to control criminal groups (Aguayo 2000).

Thus, the PRI monopolised virtually all levels of government for 71 years (1929-2000). The PRI also maintained a relative peace in Mexico compared to other countries in Latin America, integrating political dissidents, generals and caudillos into the political system, without ever resorting to armed force. Criminal groups were subordinated to the political power to "get a credential to operate". Any insubordination was viewed as treason against the political system, and the rule of law was applied against them, as an old popular Mexican saying goes: "Application of the law for my enemies, and the protection - impunity - for my friends" (Nieto 2011).

Another pillar of the Mexican system was the formal - written laws - and informal - unwritten laws and political agreements - powers of the President,

1 The National Revolutionary Party (PNR) was created in 1929 under the administration of Plutarco Elías Calles (1877-1945). It was renamed the Mexican Revolutionary Party in 1938 under the government of Lázaro Cárdenas, and in 1946, during the presidency of Manuel Avila Camacho (1897-1995), it became the PRI (Aguayo 2000).
The development of narcotrafficking and corruption in Mexico Nubia Nieto 
which controlled the political arena for many decades (Carpizo 1978: 191). Besides, another pillar of the post-revolutionary Mexican system was corruption, which became an essential element, not only in building this contemporary political system, but also in nourishing loyalties among members of the PRI, integrating dissidents, keeping the control on other parties and controlling criminal groups. Criminal groups needed to have a "special licence" to operate across the country. Many of these licences were granted for family, political or financial favours. For example, a criminal could pay for the political campaign of a politician at local, regional and national level; in exchange the trafficker could continue operating without police intervention. The criminals were also in charge of keeping the peace in areas where they operated, otherwise the agreement between politicians and criminal was broken, and traffickers would end up in prison. In that way, the PRI and political elites used the fruits of corruption and illegal drug trade as a source of power to nourish political clientelism, and to obtain legitimacy among the population (Nieto 2011). Criminals were also in charge of funding community parties and creating social infrastructure for leisure activities, roads, local clinics, refurbishment of local churches and other community facilities in the villages, where their business was based as a way to distribute some of their wealth, thanks to which the villagers gave them their approval, protection, respect and legitimacy. The corruption ${ }^{2}$ was embodied in the Mexican post-revolutionary political system and tolerated by both, the political elites and the citizens. As Alan Riding used to say, "the corruption is the oil that moves the Mexican political system" (Riding 1985: 140). As Astorga indicates, the development of drug trafficking was controlled, tolerated and regulated by the politicians, and it was developed inside the power structure, the drug traffickers were a sort of a new class of outlaws that depended closely on political and police protection (Astorga 1999: 13). The marriage between political power, corruption, and development of drug trafficking continued for almost the same period as the Mexican post-revolutionary political system (1929-2000), including the PRI, the traditional corporatist structure, and extra attributions of the president. The double discourse of the fight against corruption prevailed during many decades, and many presidents used the discourse against corruption as a way to distinguish themselves from their predecessors, to renew faith in the ideals of the Revolution and gain social legitimacy. It was a ritual carried on every six years, which diverted from a real interest in reducing corruption and implementing the rule of law. As Morris says: "Among the effects, the structural imbalances enabled the president to use corruption to cement the ties wed-

2 The term corruption is taken as the abuse of public power for private purposes. This definition assumes the distinction between public and private roles. In many societies the frontier between both spheres is not very clear and it seems to be natural to give some gifts in exchange of assigning contracts and jobs. However, in developed societies the difference between the two spaces is more pronounced. (Rose-Ackerman 1999: 91). 
ding the political elite, reward those abiding by the informal rules of the game and punish those who did not and even co-opt those potentially threatening the system" (Morris 2009: 1).

An example of the double discourse of the fight against corruption was the government of José López Portillo (1976-1982), as he emphasized his will to fight against corruption on several occasions. However, his government would end up in the middle of many corruption and drug trafficking scandals. Arturo Durazo Moreno (1976-1982), an old friend of López Portillo, was appointed as head of the General Directorate of Police and Traffic (Dirección General de Policía y Tránsito) in Mexico City. Durazo Moreno transformed this institution into a centre of corruption, drug trafficking and trade of arms. He also sent police officers to rob banks and extort financial resources from citizens for personal gain. During his ruling, Durazo built himself a US \$2.5 million mansion on the outskirts of Mexico City, with a horseracing track and a replica of the Studio 54 discotheque in New York, and in the Pacific coast resort of Zihuatanejo, his cliff-top retreat, complete with classical columns, nicknamed the Parthenon - a copy of the Greek Parthenon - (Gunson 2000). Alan Riding used to say: "Durazo converted the police into a racketeering empire that made his predecessors' performances seem positively innocuous" (Riding 1985).

\section{A change of economic model and political elites}

The government of Miguel de la Madrid Hurtado (1982-1988) introduced a new economic model, neoliberalism, which replaced the import substitution model based on protectionist policies and domestic production. The import substitution model was viewed as the main cause of the economic crises of the 1980's, not only in Mexico, but also around the world. New theories of free market, privatization of state companies and free trade flourished in the United States and the United Kingdom, led by Ronald Reagan and Margaret Thatcher. In Mexico, De la Madrid was another supporter of these theories, and his successor Carlos Salinas de Gortari (1988-1994) implemented it fully ${ }^{3}$.

The neoliberal economic reforms transformed Mexico into a giant "free market." The passage of the North American Free Trade Agreement (NAFTA) in 1994 had the effect of making Mexico heavily dependent on and more integrated with the US economy. By 2006, around $85 \%$ of Mexico's exports were sold in the United States (Redmond 2013). According to Redmond, for Mexican workers and farmers, NAFTA was like a housing collapse. In the first year

\footnotetext{
3 Neoliberalism: a late $20^{\text {th }}$ century revised "liberalism" that seeks to transfer economic wealth from the hands of the state to the private sector, also called the "Washington Consensus", because the key mechanisms for imposing fiscal discipline are the US-based International Monetary Fund (IMF), the World Bank, and other financial institutions (Meade 2010: 343).
}

The development of narcotrafficking and corruption in Mexico Nubia Nieto 
of the agreement, there were one million layoffs. At the end of 1996, there were 8 million unemployed and five million people working in the informal economy. Workers in foreign-owned export assembly plants called maquiladoras earned six dollars a day. That wage left millions of Mexican families living in poverty (Redmond 2013). As a condition of membership in NAFTA, Mexico was forced to eliminate the system of communal land sharing known as ejido - indigenous ownership form inherited by the Aztec social organization -, leaving thousands of peasants without any income and in absolute poverty (Redmond 2013). At the same time, the PRI lost more and more credibility and legitimacy to continue operating, since the National Peasant Confederation (CNC) and the Confederation of Mexican Workers (CTM) were unable to restore loyalties, submission and legitimacy among peasants and workers. Many of them migrated to the US and others looked for another sort of income in the informal market. Thousands of police officers and special forces belonging to the federal police and judicial police were fired, and the police forces were dismantled as a part of the program to reduce the size of the State and restructure the police. Later, these ex-officers, as well as peasants and street children, were recruited for the organized crime. Guerrillas and armed movements flourished in different parts of Mexico: Guerrero, Oaxaca, and the most known in Chiapas, through the Zapatista Army of National Liberation (Ejército Zapatista de Liberación Nacional - EZLN) - led by el comandante Marcos. The Zapatista army went public on January 1, 1994, the same day that NAFTA came into effect (Aguayo 2000). The government of Carlos Salinas de Gortari was closely related to the Golfo cartel, led by Juan García Ábrego. The relation of Carlos Salinas' brother, Raúl Salinas de Gortari, with this cartel was widely known in the media at that time. According to Helen Redmond, NAFTA created not only a new billionaire business elite in Mexico like Carlos Slim ${ }^{4}$, but also narco-businessmen like Joaquín "El Chapo" Guzmán Loera, the CEO of the Sinaloa drug cartel. He made the Forbes billionaire list four times and his fortune was between one and ten billion dollars. "El Chapo", a capitalist innovator of new drugs, saw the potential for huge profits in the methamphetamine market and set up super-laboratories close to the US border (Redmond 2013). The "narco-business" also created new rich families related to national politics such as Raul Salinas de Gortari, brother of Carlos Salinas, former Mexican president, and his family. In 1995, Swiss authorities found \$110 US million in accounts linked to Raul Salinas. The money-laundering proceedings against him began. Swiss detectives alleged that the funds were related to drug trafficking (Grillo 2013: 258).

4 Carlos Slim Helú is a Mexican business magnate and investor. From 2010 to 2013, Slim was ranked as the richest person in the world. He derived his fortune from his extensive holdings in a considerable number of Mexican companies through his conglomerate Telmex, América Móvil, Samsung Mexico and Grupo Carso. By July 31, 2016, he was the number 7 on Forbes list of billionaires with a net worth estimated at \$52.5 billion of US dollars (Forbes 2016). 
The development of narcotrafficking in Mexico was also benefited by the control of the US authorities over South Florida and the Caribbean, which helped to reduce the entrance of drugs to US territory. Then, Colombian organizations began forming alliances with drug traffickers based in Mexico to transport cocaine to the United States using Mexico as a route of contact, and soon the Mexican cartels gained autonomy with respect to the Colombians (Grillo 2013). The presence of the cartels' power in Mexico was each time more visible. The government of Ernesto Zedillo Ponce de León (1994-2000) soon reflected the influence of the narcotrafficking business. Following the neoliberal school, Ernesto Zedillo continued to privatize state companies and suppress peasants' movements. In Chiapas, in the south of Mexico, on December 22, 1997, 45 people, among them pregnant women and children, were brutally slaughtered, while attending a prayer service in a local church. This event was known as "the Acteal massacre". In 1994, the government of Zedillo was marked by the murder of Donaldo Colosio Murrieta, a candidate for the PRI presidency, during his political campaign. Some hypothesis indicates that his murder was due to his will to fight corruption and impunity: “¡Es la hora de cerrarle el paso al influyentismo, a la corrupción y a la impunidad!" - "It is time to close the way to influential people, corruption and impunity!" (Ramales 2005). Other political figures, who were murdered due to their alleged links with the narcotrafficking were José Francisco Ruiz Massieu, ex-governor of Guerrero, his brother Mario Ruíz Massieu, ex-attorney of the country, and Paco Stanley, a member of the Mexican show biz. Simultaneously, other member of the political elite such as the governor of Quinta Roo, Mario Villanueva Madrid (1993-1999), was arrested by orders of the Drug Enforcement Administration (DEA), after he eased the transport of drugs from Colombia to Mexico and then to the US (Ramales 2005).

\section{The political transition and the breakage of loyalties}

The arrival of Vicente Fox in 2000 to the Mexican presidency, as the candidate of the National Action Party (Partido de Acción Nacional, PAN), broke the PRI's seventy-one-year hold on power as well as it broke the informal and formal presidential attributions, opening a new period of democracy. However, simultaneously, Fox opened "the Pandora box", releasing the dark forces that had been controlled until then by the supremacy of the PRI: the narcotraffickers.

As Morris explains, before the 1940s, governors of drug-producing and trafficking states had the power to control illegal business in their territories. After 1947, anti-drug agents and the military had direct responsibility for fighting traffickers and the possibility of being institutional mediators between traffickers and political power. Neither traffickers nor mediators were autonomous: they were both subordinated to political power. The crackdown of the political regime governed by the PRI has provoked cascade effects on
The development of narcotrafficking and corruption in Mexico Nubia Nieto 
Artículos y ensayos

Image 1.

Power distributed under post-revolutionary Mexican political system

Image 2.

Power distributed under neoliberal system different levels of the power structure. Disputes among political families have disrupted the mechanisms of political control creating other conflicts between traffickers and political institutions. Institutional mediators such as police and military members can now be more autonomous than ever, and able of playing for their own interests without political commitments (Morris 2009: 33).

The image 1 illustrates, in a simple way, how the power was distributed and the fruits of corruption flowed constantly, keeping the post-revolutionary Mexican political system in relative harmony for almost seven decades between citizens, criminal groups, political leaders and political bureaucrats, including the police forces and members of the army. At the top of the pyramid was the president.

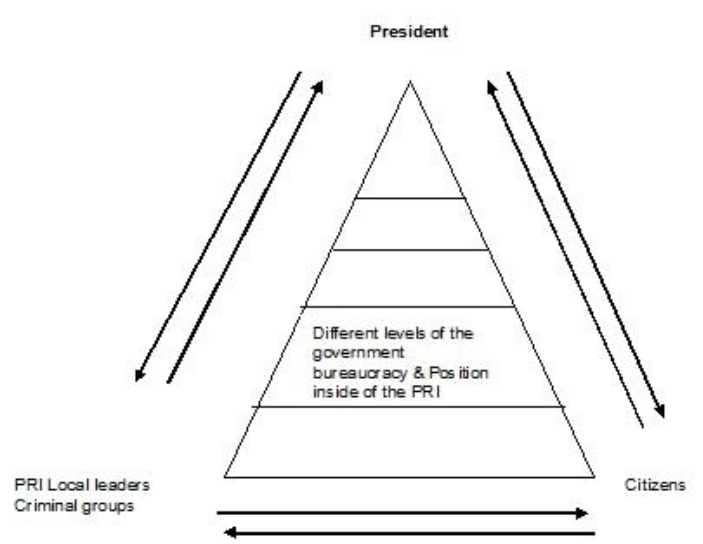

Source: Nieto, Nubia (2004), La géopolitique de la corruption. Le Mexique: une étude de cas, Ph.D. Thesis, Paris I, La Sorbonne, France; Rivelois Jean (1999b), Drogue et pouvoirs: $d u$ Mexique aux paradis, Paris, L'Harmattan.
President \& Political Elite

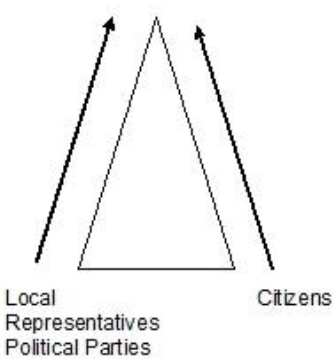

Drug Cartels Lords

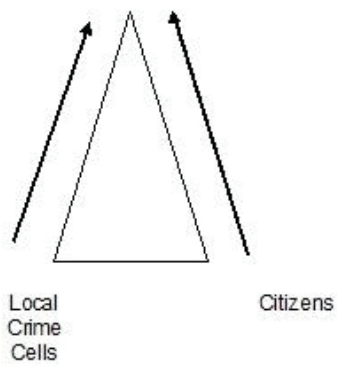

Source: Nieto, Nubia (2004), La géopolitique de la corruption. Le Mexique: une étude de cas, Ph.D. Thesis, Paris I, La Sorbonne, France; Rivelois, Jean (1999b), Drogue et pouvoirs: $d u$ Mexique aux paradis, Paris, L'Harmattan. 
Following the dismantling of the corporatist system of the PRI, the drug traffickers have obtained more autonomy to operate independently and without restrictions of the political bureaucracy, including the police and army generals, as can be seen on the image 2. By doing this, the Mexican State is confronted to equal level or even superior, by the "Narco-state" which has guns of higher calibre than the Mexican army, money and global power to confront national authorities.

What's more, the corruption is no longer distributive like in the post-revolutionary period, but rather elitist, therefore the ordinary citizens do not see any advantage of it. Local representatives of different parties are unable to hold loyalties of citizens, and citizens have more immediate and concrete demands. On the other hand, the Narco-state is led by drug cartels' lords, who reinforce their power by local crime cells using violence, torture, intimidation, kidnapping, selling protection for small business, among other methods of subjugation, without forgetting that narcotraffickers have financial resources to buy people, politicians and police forces.

As Jean Rivelois describes: "Today, the economic power of the Liberal State is less due to the fact that there is less money in the State, and less money to distribute among corruptive authorities. The opportunities for social distribution of fruits of corruption are diminishing. The corruption becomes more and more elitist" (Rivelois 1999a: 294). For Rivelois, the New Mexican State continues being structured by client relations, but it is limited in its capacity to feed its social clients, which generates a problem of legitimacy for the political powers and a problem of the tolerance of corruption among citizens (Rivelois 1999a: 294).

Certainly, up to the 1990s the structure of political power, based on the PRI, could demand a rent in exchange of turning a blind eye on the drug business, and provide state infrastructure such as roads, telecommunications, information and even protection from the police and army. However, after the 2000, without the political pyramid of the PRI and the increased power of the drug trafficking, they started to build a Narco-state ${ }^{5}$ in parallel to the Political State (Santos and Bustos 2009: 2).

Drug trafficking is a criminal activity that generates a large number of crimes. Many traffickers and illegal organizations (cartels) have been able to accumulate enormous fortunes and material means, which has given them a position of strength that allows them not only to avoid the rule of law, but also to become centres of parallel power (Santos and Bustos 2009: 2).

The Government of Felipe Calderón (2006-2012) saw an unprecedented level of violence, after he promised to eliminate drug cartels in the National

5 The Narco-State: It is the construction of the State that has been taken over and is controlled and corrupted by drug cartels, and where law enforcement is effectively inexistent or barely inexistent (Rivelois 1999a) [translation from French language].
The development of narcotrafficking and corruption in Mexico Nubia Nieto 
Program for the Control of Drugs 2006 and in the National Development Plan released on the same year (Santos and Bustos 2009: 8). Calderón faced the pressure of the U.S. regarding the increase of drug trafficking in Mexico, since Vicente Fox, his predecessor, avoided tackling the problem. Fox sent just a few troops to Nuevo Laredo -the border between Mexico and the US-, but most of the troops died fighting against the Golfo cartel and Sinaloa cartel.

In December 2006, President Felipe Calderón sent 6,500 troops to Michoacán, where violence was more notorious. Later he would send 45,000 members of the army, plus members of the local and national police, but the strength of drug traffickers proved to be more effective. From 2006 to 2012 President Calderón waged a U.S.-backed offensive against drug cartels. Fighting between rival gangs and the security forces led to between 47,000 and 70,000 deaths. More than 20,000 disappeared and a quarter million people were displaced. What's more, Calderón brought the military involvement to unprecedented levels. By 2011, there were 96,000 soldiers and 16,000 Mexican marines in the campaign against cartels, which only exacerbated the violence (Grillo 2013: 253-260).

The arrival of Enrique Peña Nieto (2012-2017), the candidate of the PRI to the Mexican presidency, was an attempt to re-establish peace in the country and negotiations with the drug cartels' lords. Since the beginning of his government, Peña Nieto switched his priorities from talking about security to focusing on the economy and reducing violence (Grillo 2013).

However, the outcome was not very optimistic. The violence in Mexico continues being high. The Executive Directorate of the National Security System (Secretariado Ejecutivo del Sistema Nacional de Seguridad Pública - SESNSP), belonging to the Ministry of National Defense (Secretaría de la Defensa Nacional-SEDENA) reported by October 31, 2016 an annual figure of 32 thousand 662 killings (Luna 2016: 4-5), and the figure does not seem to reduce. According to the Council on Foreign Relations (CFR) the number of deaths since 2006 due to the organized criminal violence in Mexico goes from 80,000 to 100,000 people until 2017 (CFR 2018), which shows the extent of the problem and the failure of the measures to fight against this global phenomenon.

The drug market, as any other business, is regulated by the market rules, which consider the levels of risk calculated as investment expenditure in comparison with the levels of profitability. The value of the drug market in the United States is estimated in the range of $\$ 30$ to $\$ 150$ billion. Drug violence is not "goons just shooting each other". This is a big business, as Canales says: "Drug cartels are incredibly complex organizations that have well-defined structures, that are able to coordinate the movement of supplies from all around the world and that must also guarantee the delivery of their product to the lucrative markets in the United States. Currently, there are an estimated 55 million users of illegal drugs in the United States and, together, they make up half of the global demand for illegal substances" (Canales 2012). Nowadays, there are a few powerful cartels, but there are more criminal cells as 
the structure of the cartels continues evolving and adapting to the new global needs and trends. For example, the new criminal cells act more independently, they hire or outsource services to other criminal cells, rather than providing all services by themselves (Davila 2016). However, some cartels sell their brand as a franchise to small cells in order to operate in their local towns or regions.

According to the Mexican press, Mexico is controlled by three cartels: the cartel of Pacífico (previously named cartel of Sinaloa), the cartel of Beltrán Leyva and the cartel of Jalisco New Generation ( CJNG) (García 2018). The CJNG controls the main tourist destinations such as Acapulco, Ixtapa, Veracruz and Puerto Vallarta. The CJNG also controls the states of Colima, Guanajuato, Guerrero, Jalisco, Morelos, Nayarit, Michoacán and Veracruz and it has huge presence in Baja California, Baja California Sur, Durango, Chihuahua, Coahuila, Sinaloa (García 2018).

However, it is recognized that there are other cartels - with less global operations and logistic scope, but equally aggressive and brutal - which fight to control similar regions and places, such as Los Zetas and Los Mata Zetas New Generation Cartel, the Noreste Cartel, Los Viagras, Los H3, the Guerreros Unidos Cartel, whose members were part of the Beltrán Leyva Cartel, the Milenio Cartel, La familia Michoacana, the Beltrán Leyva Cartel, Los Negros, La Mano con Ojos, the Colima Cartel, the Tijuana Cartel, the Juárez Cartel, the Acapulco Cartel and the Caballeros Templarios-Guardia Michoacana Cartel, among the most notorious (Davila 2016). According to the Council on Foreign Relations, it is estimated that there are over 200 drug trafficking cells in Mexico (CFR 2018).

In an interview with Celerino Castillo, a former agent of the Drug Enforcement Administration (DEA), in the state of Tamaulipas - the Northeast of Mexico -, he indicates that the main cartels outsource or hire other services to other criminal groups to reduce costs generated by paying bribes in order to maximize profits. He says, for example, "the Golfo Cartel outsource to the criminal cells of the Metros in Reynosa or to the Rojos in Matamoros, or to the Dragons in Tampico. As well as, to the Fresitas and the Cyclons in Tampico" (Redacción 2016b: 3).

Today, the drug trafficking in the Mexican Republic is one of the most serious problems facing the Mexican government and putting national security at risk (Santos and Bustos 2009: 4). Gun battles between security forces and cartel gunmen have terrified citizens, rather than making them feel safer. Residents, workers, and schoolchildren are frightened, when fire fights last hours in broad daylight. Worse, the security forces killed dozens of civilians, who failed to stop at checkpoints or were in the line of fire. Soldiers and narcotraffickers have been accused of widespread human rights abuses, including torture, rape, and murder of those people, who they detain, arrest or capture. On the other hand, the laxity of American gun laws does not help to reduce violence and narcotrafficking in Mexico. The US gun trade is a huge business
The development of narcotrafficking and corruption in Mexico

Nubia Nieto 
for the American companies. Guns and ammunition are the most successful industries in the U.S. "Just in 2015, arms sector generated $\$ 49.3$ billons, created 21,000 new jobs, and brought $\$ 6.2$ billons taxes to the US. Government" (Fernándes 2017).

In recent years, Mexican cartels have improved their weaponry power. According to the Mexican Ministry of National Defence (Secretaría de la Defensa Nacional-SEDENA) 70\% of the weapons of cartels come from the United States. Since 2012 until June 2015 the government has seized 19,848 guns, all for exclusive use of the armed forces. Most of the weapons were seized in Chihuahua, Baja California, Michoacán, Tamaulipas Guerrero, State of Mexico, Sonora and Nuevo León. According to Gomora, almost $60 \%$ of drug traffickers' weapons are .223 calibre rifles, a civilian version of the M16 of the US Army and AK 47 so-called "goat horns" (Gomora 2016).

Following the report, from 2009 to 2014, 49,566 long guns and shotguns were seized and traced, according to their origin of manufacturing. During the same period, 53,156 short guns, including revolvers and pistols, were also seized and analysed. The result shows that most of them come from the US, particularly from the Southwest, border states of Texas, California and Arizona. The logistic capability of many cartels is supported by helicopters, submarines and radars to be able to fight with Mexico's federal government on equal basis (Gomora 2016).

The entrance of firearms in Mexico becomes also more complex. From a sample of 104,850 firearms seized by Mexican authorities and submitted for tracing between 2009 and 2014, the United States reach the top of the six countries of firearms seized and traced in Mexico, the others countries are Spain $(3,786)$, China $(3,027)$, Italy $(2,186)$, Germany $(1,522)$ and Romania $(1,287)$ (Gomora 2016).

Perhaps it is important to underline that in Mexico gun ownership is regulated by the State ${ }^{6}$, even more, in recent years the Mexican Senate approved on December 15, 2016 a new law that condemns illegal carrying of weapons with penalty ranging from six months to 30 years in prison for those who carry weapons (Cardoso 2016c: 16).

For Celerino Castillo, a former agent of the DEA, "the problem facing the United States is not so much about drug trafficking, but its addiction to money". In this regard, it should be noted that from 2010 to 2012, more than 253,000 weapons were used in the northern border of Mexico, which were acquired in the licit and illicit US market, resulting in gains for the US arms industry, giving profits to the US firearms industry just for this amount of guns of around

6 The Mexican Constitution grants the right to use guns to citizens, but under the State control, as it says in the article 10: “ The inhabitants of the United Mexican States are free to possess arms of any kind, for their security and self-defence, made exception of those prohibited by law and those ones that the nation reserves for the exclusive use of the Army, National Guard Army; but they -inhabitants- will not be able to carry them in the towns without being subject to police regulations" (Constitución 1917). 
127 million of US dollars - around 2 thousand 400 million of Mexican pesos. The weapons that arrive from the United States to the Mexican Army most of the times end up in the hands of organized crime (Redacción 2016b: 3). The development of the narcotrafficking in Mexico is a result of the high levels of corruption in the country, without forgetting the responsibility of US authorities, as Castillo put it "without the approval of the authorities, these businesses could not be possible" (Redacción 2016b: 3). For Peter Dale, the development of the narcotrafficking is due to "the protected intelligence-drug connections". For example, Dale says, “The Guadalajara Cartel, Mexico's most powerful drug-trafficking network in the early 1980s, prospered largely because it enjoyed Mexican and US protection. Under these circumstances, members of the Guadalajara Cartel became prominent among the drug-trafficking supporters of the CIA's Contra operation" (Dale 2000: 2).

\section{The increase of local powers and corruption}

After the year 2000, the following presidents of the country opened the door to the implementation of federalist policies as a way to implement social democratic demands. However, the federalist principle also trigged other consequences for the development of corruption and drug trafficking, as Enrique Krauze put it: "we pass from an imperial presidency to imperial caciques" (Krauze 2016). According to Krauze, the imperial caciques are represented by state governors, state directors of the judicial and federal police and local authorities. It is no coincidence that in those Mexican states, which present high levels of public debt, corruption and impunity, there are also high levels of violence and narcotrafficking disputes. For example, the ex-governors of Coahuila (Humberto Moreira 2005-2011), Durango (Jorge Herrera 2010-2016), Nuevo León (Rodrigo Medina 2009-2015), Tamaulipas (Egidio Torre 2011-2016), Chihuahua (César Duarte 2010-2016), Veracruz (Javier Duarte 2010-2016) and Sonora (Guillermo Padrés 2009-2015) have created a public debt of 186,553 million of Mexican pesos (around 9.70 billion US dollars). The public debt registered by those governors is 20.6 times higher than the total budget allocated for the agriculture, 909.9 times higher than the 205 million Mexican pesos (around 9.97 million US dollars) allocated for the National Institute for Women, and 709.2 times bigger than the 263 million Mexican pesos (about 12.8 million US dollars) assigned to the fund for the help of immigrants (Cardoso 2016a: 6-7) ${ }^{7}$. Parallelly, the same states also present high levels of violence. Several of the Mexican governors, who were mentioned earlier are also involved in cases of corruption, money laundering and are linked with narcotrafficking. A case in

\footnotetext{
7 The average Mexican exchange rate as of November 2016: one US dollar equal to 20.5720 Mexican pesos (Global currencies 2018).
}

The development of narcotrafficking and corruption in Mexico Nubia Nieto 
point is Humberto Moreira, ex-governor of Coahuila (2005-2011), who was arrested by the Spanish government in January 2016 on charges of money laundering and embezzlement during his term as governor of the Coahuila state. However, in Mexico, Moreira did not have any record of corruption. He was a former president of the PRI in 2011 with a "transparent reputation". After negotiations taken up by the Mexican government in defence of Moreira, he was released, and he abandoned Spain immediately. Then, in Mexico, he wanted to be re-elected as a local deputy of the PRI in Coahuila in the elections held on June 4, 2017, but he stopped his political ambition after local pressures (Del Llano 2016).

Since 2006, the fight against narcotrafficking at local and national level has been carried out by local and national police grouped by preventive and judicial police, which can be federal, state or municipal police, and by the Mexican army forces, which are composed by the Army, the Air Force, and the Navy (Constitución 2017). The Mexican Political Constitution promulgated in 1917 establishes in the Article 13 military jurisdiction and determines its scope. The Article 129 indicates that in times of peace, no military authority can exercise more functions than those that are exactly in connection with military discipline: "In times of peace, no military authority can exercise more functions than those that have an exact connection with military discipline. There will only be military basis fixed and permanent in castles, fortresses and warehouses that depend immediately on the Congress" (Constitución 2017). The article 29 of the Constitution regulates the suspension of fundamental rights by orders of the Executive Power, with the approval of Congress, in case of situations or states of emergency (Constitución 2017). On the other hand, the articles 16, 29, 89, fraction VI, and 129 of the Mexican Constitution indicate that it is possible that the Army, Air Force and Navy at times when no suspension of guarantees has been decreed, may act in support of civil authorities in various tasks of public security (Carbonell 2002).

However, in recent times, "civil liberties groups, journalists, and others have criticized the Mexican government's war against cartels for years. A 2016 Human Rights Watch report says that Mexico's security forces have been linked to the extrajudicial killing of thousands of civilians and the disappearances of twenty-seven thousand people since 2006" (CFR 2018). There are many examples of abuses perpetrated by the army, some known by the national and international public, and other ones that have passed unnoticed by the press, for example, "mass protests erupted across the country in 2014 after forty-three students disappeared in the town of Iguala, in the state of Guerrero, following deadly clashes with local police. Mexican investigators found that the police handed the students over to a local drug gang at the behest of the mayor, who had ties to the gang. The incident showed "a failure of the political system to root out close links between the cartels and political parties” (CFR 2018).

Certainly, the role of the Mexican army has been highly questioned in the process of fighting against narcotrafficking due to the numerous human 
rights abuses and high levels of corruption inside of the police and army hierarchy, but it is well recognised that the navy, which did not enjoy high levels of social and political prestige during decades, has showed to be more efficient at fighting organised crime. The Mexican intelligence services coordinated by the Ministry of National Defence (SEDENA), the Executive Directorate of the National Security System (SESNSP) and the National Security Research Center (Centro de Investigación y Seguridad Nacional $-\mathrm{CISEN})^{8}$ have also worked closely with the Mexican army at fighting narcotrafficking. Nevertheless, the narcotraffickers continue being strong and present in the whole country.

\section{Conclusions}

The narcotrafficking in Mexico has been developed hand in hand with corruption. Together, they have perverted not only the political regime, the national security, the social peace, but also they have perverted the democratic process and the development of the country. There are many factors that have contributed to the development of narcotrafficking and violence in Mexico at both international and national level. Among international factors are "the protected intelligence-drug connections", a global trade phenomenon, a business that generates huge revenues, and a business which is connected to other complex criminal activities such as gun trafficking and human trafficking. At a national level, the development of narcotrafficking has been easier because of the dismantling of the social and political pyramid of the PRI's structure, as well as high levels of corruption and impunity inside of the public institutions, together with other factors such as high levels of social inequality, poverty and unemployment, poor performance of the rule of law, historical agrarian conflicts, lack of opportunities for social mobility based on meritocracy, without forgetting the disconnection between political elites and average citizens, the cynicism and opportunism of politicians and the wrong perception among political elites about public function, considered as an opportunity to create personal wealth instead of an opportunity to serve and help to enrich public service.

The financial perspective cannot be forgotten as it is a key factor, which has facilitated the development of the narcotrafficking in Mexico not only because of the huge revenues, which drug markets generate for the cartels, but also because of politicians, police members and average citizens, who get more

8 It is important to mention that the Center for Research and National Security (CISEN) will disappear with the arrival of the new government of Andrés Manuel López Obrador announced in September 2018. The intelligence functions of the CISEN will be assumed by the new Federal Secretariat of Public Security, which is led by Alfonso Durazo Montaño. The dismantlement of this institution is due to its failure at reducing violence and promoting corruption (El Economista 2018).
The development of narcotrafficking and corruption in Mexico

Nubia Nieto 
money through drugs and corruption channels than working long hours for poor pay. At a social level, the development of narcotrafficking has been facilitated by several elements such as the pursuit of the "narco-dream" of having money, women, arms, power and all excess available in an easy way; a "macho culture", which uses violence as a way to prove masculinity; the projection of narcotraffickers as heroes through the "narco-corridos", a musical gender based on narrative which glorifies drug traffickers' work and lifestyle: the social acceptance, tolerance and admiration of narcotraffickers, leading even to the sanctification of the "narcosanto"- narcosaint - Jesús Malverde (18701909), known as a "generous bandit" or "angel of the poor", who is considered a hero in the Mexican state of Sinaloa (Univision 2015).

The development of narcotrafficking has also been facilitated by the use of the social media, such as You Tube or Facebook, by criminal groups which use them not only to show videos of hanging, torture and brutal killings, but also to advertise job vacancies for criminal activities and sell drugs through the "dark net". The process of globalization has been another key factor in the development of narcotrafficking in Mexico, since many criminal cells and cartels operate on a global trade and manufacturing basis. The Mexican narcotrafficking is also more complex as it is merged with other criminal activities such as human trafficking, kidnapping, money laundering, extortion, bribery, racketeering, and weapons trafficking.

The consequences of the mixture of corruption and narcotrafficking in Mexico has disastrous effects, particularly for the most vulnerable groups who are the target of criminals. For example, in many rural villages, the narcotraffickers force indigenous groups to cultivate marijuana and, if the indigenous people refuse to do it, the traffickers kill, rape and torture the entire village. On the other hand, if the indigenous people accept to cultivate marijuana, when the army members arrive to those villages, they kill, rape and torture them on the grounds of helping or being part of a cartel. In Mexico "cartels have used vast drug profits to neutralize government opposition, paying off judges, police, politicians, and other officials" (CFR 2018) to control or manipulate the application of the rule of law.

However, Mexico is in a key moment to implement the rule of law, particularly after the triumph of Andrés Manuel López Obrador (AMLO) as the president-elect of the country (July 2, 2018), whose main political compromise during his campaign was to fight corruption. He already proposed 50 principles to reduce corruption and public deficit. Among the most important are:

"1. Reform Article 108 of the Constitution so that the acting president can be tried for electoral crimes and related to acts of corruption.

2. Suspension of all privileges for public officials.

3. Reform of the law to consider as serious crimes the influence peddling, corruption, the association between officials and individuals to commit fraud to the Treasury, fuel theft and electoral fraud in any of its modalities. Penalties will not allow the accused to obtain bail. 
4. The Attorney General's Office will have absolute autonomy and its practices will appeal to the principle of liberal law within the frames of the law, nothing and nobody above the law.

(...)

7. All officials must present the declaration of their and their close relatives assets. It will be transparent in all cases.

8. The president will earn less than half of what president Enrique Peña Nieto receives: he will earn $40 \%$ less than the 270,000 pesos a month that Peña Nieto currently receives, that is, his salary will be of 108,000 pesos". (Milenio 2018).

Certainly, AMLO has an ambitious programme to fight corruption, impunity and reduce violence in the country, which gave him a huge advantage in comparison to his opponents. The arrival of AMLO, with the coalition "Juntos haremos historia" (together we will make history), which is composed by the Worker's Party (Partido de los Trabajadores - PT), National Regeneration Movement (Movimiento de Regeneración Nacional - Morena) and Social Encounter (Encuentro Social), reached the highest representation in the elections with 53.1936\%, representing 30,113,483 votes, against Ricardo Anaya Cortés of the Coalition for Mexico at Front (La coalición por México al frente), composed by the National Action Party (Partido de Acción Nacional - PAN), Party of the Democratic Revolution (PRD) and Citizen movement, which reached $22.2750 \%$ with $12,610,120$ votes. José Antonio Meade Kuribreña, who represented the coalition All for Mexico (Todos por México), comprised by the Institutional Revolutionary Party (PRI), Mexican Ecologist Green Party (Partido Verde Ecologista Mexicano - PVEM) and the New Alliance Party (Partido Nueva Alianza - Panal) achieved 16.4099\%, with 9,289,853 votes (INE, 2018). Andrés Manuel López Obrador has also announced his strategy to reduce violence in the country through a pacification plan: "First it is to close the cycle of war, second, to achieve a turning point of criminal violence within 180 days, three, to recover the confidence of society in the security forces, projected in three years and, finally, deliver a country in peace and tranquillity in 2024 " (Fregoso 2018). The new president has announced serious social, political and economic reforms, which may reduce the level of violence and corruption in Mexico. However, it is necessary to be aware that six years of government is not enough to resolve historical problems, dating from centuries ago, and put an end to a global problem which requires a global governmental initiative, as well as a strong bilateral US-Mexico responsibility. US should stop blaming only Mexico for the development of the narcotrafficking, as Americans are also responsible not only for the high demand of the product, but also for the laxity of American gun laws and for protecting financial profits of US companies, instead of well-being of people.
The development of narcotrafficking and corruption in Mexico

Nubia Nieto 


\section{Bibliographic references}

Aguayo Quezada S. (2000), El Almanaque mexicano, México, Grijalbo

Anguiano A. (1975), El Estado y la política obrera del cardenismo, México, Era.

Astorga L. (1999), Drug trafficking in Mexico: A First General Assessment, France, United Nations Educational Scientific and Cultural Organization (UNESCO).

Buendía M. (1983), La CIA en México, México, Océano.

Bureau for International Narcotics and Law Enforcement Affairs (BINLEA) (2017), International Narcotics Control Strategy Report, vol. 1, U.S.A, United States Department of State - BINLEA.

Cardoso G. (2016a), Saquean y endeudan sus estados, "Unomásuno”, México, November 21.

Cardoso W. (2016b), Mujeres del narco, “Unomásuno”, México, December 9.

Cardoso G. (2016c), Carcel por portar armas de forma ilegal, "Unomásuno”, México, December 16.

Carbonell M. ( 2002), El rol de las Fuerzas Armadas en la Constitución Mexicana, "Ius et Praxis", vol. 8, no 1, pp. 35-51.

Carpizo J. (1978), El presidencialismo mexicano, México, Siglo XXI.

Canales R. (2012), The deadly genius of drug cartels. Conference delivered in the USA, TED talks. [On line] Available: http://www.ted.com/talks/rodrigo_canales_the_deadly_genius_ of_drug_cartels.html [Retrieved August 17, 2018].

Constitución Política de los Estados Unidos Mexicanos (CPEUM) (1917), Constitución publicada en el Diario Oficial de la Federación el 5 de febrero de 1917. Texto vigente, última reforma publicada 24-02-2017 (2017). México, Cámara de Diputados del Honorable Congreso de la Unión Secretaría de Servicios Parlamentarios. [On line]

http://www.ordenjuridico.gob.mx/Constitucion/1917.pdf [Retrieved September 30, 2018].

Council Foreign Relations (CFR) (2018) Mexico's Drug War, New York, US, CFR. [On line: https://www.cfr.org/backgrounder/mexicos-drug-war] [Retrieved September 30, 2018].

Dale Scott P. (2000), Washington and the politics of drugs, "Variant", vol. 2, no 11, summer, pp. 2-5.

Davila P. (2016), Triangulo Dorado: el crimen manda, "Proceso", May 28.

De Llano P. (2016), Un juez envía a prisión a Humberto Moreira tras su detención en España, "El País", January 16.

El Economista (2018), Sí desaparecerá el Cisen: Sánchez Cordero, México, September 11.

Fernandes Silva J. (2017), The Economics of Firearms, “The Market mogul”, US, February 26. Available [online]: https://themarketmogul.com/the-economics-of-firearms/ [Retrieved January 20, 2018].

Fregoso J. (2018), López Obrador vs la violencia narco: los planes del nuevo presidente mexicano y la reacción de los cárteles ante un cambio inédito, Infobae, Julio 7.

[On line]

https://www.infobae.com/america/mexico/2018/07/07/lopez-obrador-vs-la-violencianarco-los-planes-del-nuevo-presidente-mexicano-y-la-reaccion-de-los-carteles-ante-uncambio-inedito/ [Retrieved September 26, 2018]. 
Forbes (2016), List of the top 10 billionaires in the world, US, Forbes editions, July 31.

García J. (2018), Los 3 cárteles de la droga más poderosos en México, "El Diario", New York. [On line] Available: https://eldiariony.com/2018/04/10/los-3-carteles-de-la-droga-maspoderosos-en-mexico/ [Retrieved August 28, 2018].

Gutiérrez-Romero R. (2018), Making Bad Economies: The Poverty of Mexican Drug Cartels, The United Kingdom, Oxford University, oxford research group. [On line] Available:

https://www.oxfordresearchgroup.org.uk/Blog/making-bad-economies-the-poverty-ofmexican-drug-cartels [Retrieved August 28, 2018].

Gómora D., Muedano, M., García, D. (2016), Mexican drug cartels reinforce their fire power, "El Universal", Mexico, January 24.

Grillo I. (2013), Mexican Cartels: A Century of Defying U.S. Drug Policy, “The Brown Journal of World Affairs", USA, Brown University, Winter, issue I, vol. XX, pp. 253-265.

Global Currencies (2018), Historical currencies, Spain, investing.com. [On line]:

https://es.investing.com/currencies/usd-mxn-converter [Retrieved August 20, 2018]

Gunson P. (2000), Arturo Durazo, “The Guardian”, August 14.

Instituto Nacional Electoral (INE), (2018), Resultados electorales 2018, México, IFE. [On line] https://www.ine.mx/voto-y-elecciones/resultados-electorales/ [Retrieved September 20, 2018].

Krauze E. (2016), Democracia en Construcción, Ensayista Liberal 6, México, Debate.

Luna E. (2016), 32 mil 662 homicidios en el año, “Unomásuno”, November 27, pp. 4-5.

Meade T. A. (2010), A history of Modern Latin America. 1800 to the Present, The United Kingdom, John Wiley \& Sons ltd.

Morris S. D. (2009), Political Corruption in Mexico. The impact of Democratization, USA, Lynne Rienner publishers.

Milenio (2018), Los 50 lineamientos de AMLO para la austeridad y contra la corrupción. México, "Milenio Diario", julio 15, 2018. [On line] Available: http://www.milenio.com/ politica/los-50-lineamientos-de-amlo-para-la-austeridad-y-contra-la-corrupcion [Retrieved August 28, 2018].

Nieto N. (2011), La socialización de las élites políticas mexicanas a través de la corrupción, "Análisis Político", Universidad Nacional de Colombia, pp. 165-181.

Nieto N. (2004), La géopolitique de la corruption. Le Mexique: une étude de cas, Ph.D Thesis, Paris I, France: University of Sorbonne.

Ramales Osorio M. C. (2005), El Sexenio Zedillista (1994-2000): El Agotamiento del Sistema, "Observatorio de la Economía Latinoamericana", no 51, November.

Redmond, H. (2013), The Political economy of the Mexico's drug war, "International Socialist Review", issue 90, July.

Redacción (2016 a), Equivale la exacción a 10\% del PIB, “Unomásuno”, México, October 27. Redacción (2016 b), Gobierna el narco Tamaulipas, “Unomásuno”, México, November 28.

Rivelois J. (1999a), Drogue, corruption et métamorphoses politiques, application à une comparaison Mexique-Brésil, Revue Tiers Monde, vol. 40, no 158, pp. 271-296.

Rivelois J. (1999b), Drogue et pouvoirs: du Mexique aux paradis, Paris, L'Harmattan.
The development of narcotrafficking and corruption in Mexico

Nubia Nieto 
Riding A. (1985), Vecinos Distantes. Un retrato de los mexicanos. México, Joaquín MortizPlaneta.

Rose-Ackerman S. (1999), Corruption and Government: Causes, Consequences and Reform, Cambridge: Cambridge University Press.

Santos Villarreal G., Bustos Cervantes C. (2009), Instrumentos internacionales signados por México en materia de narcotráfico, México, Cámara de Diputados LX Legislatura, Servicios de investigación y análisis, Subdirección de Política Exterior.

Univisión (2015), La leyenda de Jesús Malverde: Santo de los Narcos, Los Angeles, US., July 30. 